\title{
Research on the Training of College Teachers' Practical Teaching Ability under the Background of the Application-Oriented Transformation
}

\author{
Chunbo Zuo
}

\author{
Jilin Teachers' Institute of Engineering and Technology, Master Graduate Student, Assistant \\ Research Fellow. (Changchun,Ji Lin.130052)
}

Keywords: Application-oriented transformation; College teachers ;Practical teaching ability

\begin{abstract}
Through the investigation of 9 application oriented overall transformation of colleges and universities in Jilin Province, this paper analyzes and arranges the problems existing in the training of teachers' practical teaching ability in the transition colleges and universities on the understanding situation, the training mechanism and the joint training of school and enterprise.

Practical teaching is the key factor to determine the successful transformation of the application-oriented undergraduate colleges and universities while the teachers' practical teaching ability determines the quality of practical teaching method. [1] Based on the survey of 8 application oriented universities in Jilin Province, combined with the actual situation of the training of teachers' practical teaching ability in Jilin Teachers' Institute of Engineering and Technology, this paper analyzes the existing problems and causes of current practical teaching ability of applied transformation universities. And the corresponding countermeasures are put forward.
\end{abstract}

\section{Analysis on the Problems Existing in the Practical Teaching Ability Training of College Teachers in the Application-oriented Transformation}

Insufficient Number of Teachers in Practice Teaching. Practical teaching has a characteristic of strong comprehensive quality, whose teaching content and process are rather complicated. Teachers need not only a solid theoretical foundation, but also a strong ability to practice and manipulate. Therefore, the requirements for the quality of the practice teachers are relatively high. At present, the theoretical knowledge and practical experience of teachers in transition colleges and universities are disjointed. Most teachers lack a kind of ability in the course of teaching, which is to transform the related knowledge and practical ability of industry and profession into the content of education and teaching. The result is that the practical teachers' theoretical foundation is not enough, so the theoretical course teachers can't bring practical lessons, and the number of practical teachers who are fully competent for practical teaching and training courses is seriously insufficient.

Lack of Knowledge of Practical Teaching Ability. Bound by traditional educational ideas and means of education, as well as the influence of the long term theory theoretical teaching as main aspects and practical teaching as a supplement, the knowledge of most teachers in the application-oriented university is not enough in the orientation of running a school, training of talents and the practical teaching ability of Teachers. The energy they spend on the practice of teaching is obviously insufficient. At the same time, they regard practical teaching as a supplement to the teaching of theoretical knowledge, and attention are only paid to the form and content are despised. The quality of talent training is still measured by the academic performance of the students. [2] This will not only affect the quality of practical teaching and the training of applied talents, but also can not meet the needs of the application-oriented transformation.

The Single Source Structure of the Practical Teaching Teacher. Most of the teachers in the transition universities come from academic or research universities, whose scientific research ability and theoretical level are in high status. But large amount of them lack the first line work experience in production, construction, management, and service as well as practical experience. These teachers have quiet well academic background and solid theoretical foundation, but lack in practical teaching skills, which affects the whole teaching results and the cultivation of students' professional practice ability.[3] 
Unsound Incentive Mechanism in Practical Teaching. As for teachers' ability to practice teaching, it lacks the system of authoritative certification and evaluation. At present, the country has not widely carried out the certification work on the practical teaching ability of college teachers, which leads to the result that teachers have no goal in the promotion of practical teaching ability. As a result, the work is difficult to carry out effectively, and the mechanism of rewards and punishment is missing. It directly affects the improvement of the practical teaching ability of the teachers in the application-oriented undergraduate colleges. [4] In addition, the level of teachers' scientific research and the results of teaching are the main factors to be emphasized when the evaluation documents are made in colleges and universities. There is no clear target requirement for the teachers' practical teaching level, which is bound to affect the improvement of the practical teaching ability of the teachers in the applied undergraduate colleges.

Imperfect Training Mechanism of Practical Teaching. There is a serious lack of time and opportunity for professional practice training for college teachers in transition at present, which leads to the difficulty of improving their practical ability. In spite of the establishment of a systematic training and training institution for teachers, and the importance of improving the professional practical ability of teachers is also realized. But because of the limitations of various factors, there is still a lack of a sound training mechanism for teachers' practical teaching ability. The system of teachers' practical teaching and training needs to be perfected indeed because the training effect is not ideal and there is a formalization outside, which is not conducive for the improvement of teachers' practical teaching ability.[5]

School Enterprise Cooperation, Paying Great Amount of Attention to Student Training Rather Than Teacher. School enterprise cooperation is an important way of communication and communication between enterprises and university teachers. Most of the colleges and universities in application-oriented transformation have different forms of cooperation with the related enterprises. But their integration is not enough to form an effective scale. And most of them are students' internship bases. In the content of cooperation, they attach importance to the cultivation of students, while ignoring the training of teachers. In addition, in the school enterprise cooperation, the initiative service enterprise consciousness of the university teachers is weak and the ability of them is limited. It is insufficient for enterprises to accept college teachers and students to carry out practical exercise. Because of lack of government participation and guidance, the effect of cooperation is not good.[6] It is difficult for teachers to improve their practical teaching ability through the platform of cooperation.

\section{The Countermeasures to Cultivate the Practical Teaching Ability Training of College Teachers in the Application-oriented Transformation}

The training of practical teaching ability of college teachers in application transformation is a process of dynamic change. This requires us to start with the teachers' own ideas and knowledge and skills, the educational management mechanism of the school and the policy guidance of the government. We should continue to practice, to improve, and to promote.

Changing the Traditional Education Concept, Improving the Understanding of the Practical Teaching Ability. The goal of the application-oriented transformation undergraduate colleges to cultivate applied talents is as follows: they aim to cultivate high level applied specialized talents with certain knowledge and comprehensive qualities as well as sustainable development potential to meet the needs of front-line positions such as production, construction, management and service.[7] They focus on cultivating applied talents with strong social adaptability and competitive ability, which emphasizes the practical, technical ability of personnel training, and pays particular attention to the training of students' practical ability. Influenced by the traditional education concept, the university teachers in the transition pay more attention to the teaching of theoretical knowledge while disregard the training of practical operation ability. Their practical experience in practical undergraduate education is insufficient, and enthusiasm for improving their own practical teaching ability is not high indeed. It is difficult to cultivate practical talents suitable for the requirements of the times. To this end, in the transition, colleges and universities should 
strengthen guidance method to make teachers change the traditional educational concept and improve teachers' recognition of applied talents. So that they can actively renew their knowledge structure and strengthen the practice of practical teaching. As a result, they can effectively combine theory with practice and effectively transform them into education and teaching ability.

Perfecting the Mechanism of Post Training and Improving the Teaching Ability of Teachers in Practice. The training of teachers' practical teaching ability is a long-term project. It needs coordination and scientific planning of colleges and universities.[8] In order to meet the needs of the training in the applied talents, colleges and universities in transition should actively broaden the training and training ways of teachers. Through the formulation of scientific training program and training system, teachers should be actively guided to improve their practical teaching ability.

First of all, the school should do a good job in school training. It should integrate the existing teaching resources and adopt a learning method, that is, the experienced people teach the inexperienced people, the older people guide the young people to building a reasonable structure of "Double Teachers" team. It makes teachers have the ability and quality of both theoretical and practical teaching at the same time. Secondly, we should do a good job of training in and out of school. Through these way, which is to arrange teachers to carry out practical learning in the enterprise, and hire experts from enterprises and industry to carry out training and communication in schools, the training of teachers' practical ability can be strengthened. Thirdly, the system of teacher practice teaching ability training system for lifelong system should be established. Whether before or after the job, the practice of teachers in the production line and the experience of personal experience in the related industries should be highly valued. Fourthly, strengthen the training measures of teachers' practical teaching ability. For application-oriented teachers, the clear requirements should be put forward. Occupation qualification certification, enterprise testing and training, internships and other methods should be taken to carry out effective training work.

Establishing a Scientific Evaluation System, Perfecting the Incentive Mechanism of Practice Teaching. The construction of the evaluation system is the key to improving the teaching effect and quality. For the scientific evaluation system of teachers' practical teaching ability, it is not only to meet the needs of teachers to engage in scientific research, but also to meet the sincere desire for teaching.[9] First of all, college teachers in transition should be guided to improve the ability of practical teaching. We can draw lessons from scientific research rewards and teaching results. Secondly, the experience and performance of teachers' practical teaching should be included in the basis condition of job promotion, job title evaluation and salary incentive. Only by linking the improvement of teacher's practical teaching ability with its own development can teachers' enthusiasm and initiative be mobilized mostly, which will enable them to perform their teachers' duties better.

Strengthening the Construction of Practical Teaching Bases, Building up a Platform for Improving the Ability of Practical Teaching. On the one hand, the universities of application-oriented transformation should attach importance to the construction of the laboratory, practice and training base. On the other hand, they should also strengthen the cooperation between school and enterprise and build a practical training platform outside school. Enterprise is a valuable resource and an important platform for improving teachers' ability to practice teaching. Universities and colleges should give full play to the role of the cooperation platform of school and enterprise research and study, and encourage teachers to practice more in enterprises. In this way, teachers can make a timely and comprehensive grasp of the enterprises, the frontier technology and methods of the industry, and the changes in the demand for talents of society.[10] In the activities of production, teaching and scientific research jointly carried out by teachers and enterprises, the comprehensive quality of teachers' practical skills, scientific research ability, innovation ability and communication and coordination ability will be greatly improved.

Increasing the Government Investment, Building a High Quality Teacher Team in Practical Teaching. Application-oriented transformation is put forward to meet the needs of the social and economic transformation and development. Its goal is to train high technology applied talents to meet the production, construction, management and service base of regional and local economic 
development. The local government should give full play to its function. For the first is in the exchange and cooperation between college and enterprises, relevant laws and regulations on school enterprise cooperation should be formulated. And the positive guide through policy should be conducted. The second is to establish professional qualification training system for professional teachers. They should be guided by the scientific guidance, professional training, and be verified by unified certification. The third is to increase investment. In recent years, local universities have developed rapidly while there is a serious lack of resources for running a school. The government's investment in colleges and universities is mainly for the construction of the school infrastructure and the salary allowance of the school staff, etc. And it spends less on teachers' training activities. Therefore, the government should bring the cost of teacher training into financial allocation. Only by authentically increasing the training of teacher training can the level of teaching be improved.

\section{References}

[1] Nameless:Southern Metropolis Daily,(2014)No.5(In Chinese)

[2] Meihua Chen:Journal of Henan Mechanical and Electrical Engineering College, (2017)No.5,p.14-17(In Chinese)

[3] Huanyun Xiao:Logistics Science and Technology,(2015)No.2,p.64-66(In Chinese)

[4] Jixiang Yao:Journal of Hefei University Technology, (2010)No.3,p.139-142(In Chinese)

[5] Renlong Shu:Teacher Education Research.,(2011)No.3,p.31-35(In Chinese)

[6] Lian Pan:Education Space,(2016)No.9,p.128-129(In Chinese)

[7] Binglin Gu:Tsinghua University Education Research,(2014)No.12(In Chinese)

[8] Liyong Meng:the Exploration of Higher Education,(2016)No.3,p.77-78(In Chinese)

[9] Liu Ye:Journal of Sichuan University of Arts and Science,(2015)No.1,p.154-157(In Chinese)

[10]Xiaojing Li:Journal of Chongqing Electronic Engineering Career Academy,(2013)No.11,p.83-85(In Chinese) 